\title{
Characterization of sunflower oils obtained separately by pressing and subsequent solvent extraction from a new line of seeds rich in phytosterols and conventional seeds
}

\author{
Marta R. Aguirre, Joaquín Velasco and M. Victoria Ruiz-Méndez ${ }^{\star}$ \\ Instituto de la Grasa C.S.I.C, Avda. P. García Tejero, 4, 41012 Sevilla, Spain
}

Received 3 June 2014 - Accepted 16 July 2014

\begin{abstract}
In this study we evaluate the chemical composition of sunflower oils obtained separately by pressing and subsequent solvent extraction from a new seeds rich in phytosterols (IASP-18) and conventional seeds (HA-89). Results have shown that the total content of oil was much lower in the IASP-18 (18.1\%) than in the conventional (37.5\%) seeds. The extraction yield obtained by pressing was as low as 3\% in the IASP-18 seeds and $37.5 \%$ in HA-89, while in the solvent extraction it was of the same order $(\sim 18 \mathrm{wt} \%$ on seeds extracted by pressing) for the two types of seeds. No significant changes in the fatty acid composition were found between the oils extracted by the two procedures, but the pressed oils presented significantly lower acidity and larger content of the unsaponifiable fraction. Expressed as free sterols, the total sterols were 37-38\% more concentrated in the oils extracted with solvent, reaching amounts of 13700 and $6500 \mathrm{mg} / \mathrm{kg}$ in the IASP-18 and HA-89 oils, respectively. No substantial differences were found in the composition of total sterols analysed as free sterols between the oils extracted with the two procedures, but the contents of free sterols and sterol glycosides were much higher in the oils extracted with solvent.
\end{abstract}

Keywords: Sunflower oil / pressing / solvent extraction / phytosterols

\begin{abstract}
Résumé - Caractérisation des huiles de tournesol obtenues séparément par pressage et extraction ultérieure par solvant à partir des nouvelles graines riches en phytostérols et des graines conventionnelles. Dans cette étude, nous évaluons la composition chimique des huiles de tournesol obtenues séparément par pressage et ultérieure extraction par solvant, à partir de nouvelles graines riches en phytostérols (IASP-18) et des graines conventionnelles (HA-89). Les résultats ont montré que la teneur totale en huile était beaucoup plus faible dans l'IASP-18 (18,1\%) que dans les des graines conventionnelles $(37,5 \%)$. Le rendement d'extraction obtenu par pressage était aussi bas que $3 \%$ dans les graines de l'IASP-18 et de 37,5\% dans les HA-89, tandis que dans le solvant d'extraction, il était du même ordre ( $\sim 18 \%$ en poids des graines extraites par pressage) pour la deux types de graines. Aucune modification significative de la composition en acides gras n'a été trouvée entre les huiles extraites par les deux procédures, mais les huiles pressées présentaient une acidité significativement inferieur et supérieure teneur de fraction insaponifiable. Exprimé en stérols libres, les stérols totaux étaient 37-38 \% plus concentrés dans les huiles extraites avec solvant, atteignant, respectivement, les montants de 13700 et $6500 \mathrm{mg} / \mathrm{kg}$ dans les huiles d'IASP-18 et de HA-89. Aucune différence substantielle n'a été trouvée dans la composition de stérols totaux analysés sous forme de stérols libres entre les huiles extraites avec les deux procédés, mais le contenu de stérols libres et les glucosides de stérols étaient beaucoup plus élevés dans les huiles extraites avec solvant.
\end{abstract}

Mots clés : Huile de tournesol / pressage / extraction par solvant / phytostérols

Expressed as free sterols, total sterols were $37-38 \%$ more concentrated in the solvent extracted oils compared to the

\footnotetext{
^ Correspondence: mvruiz@ig.csic.es
}

pressed oils. The former showed higher contents of free sterols and sterol glycosides and the pressed oils were characterized by higher relative concentrations of sterol esters. 


\section{Introduction}

Vegetable oils are the richest natural sources of phytosterols, followed by cereal grains and nuts (Piironen et al., 2000). Phytosterols and the related phytostanols are essential components of plant cell membranes. They are C28 and C29 steroidal alcohols and differ from the C27 sterols such as cholesterol, commonly found in animal cell membranes. Plants do also contain cholesterol but only in very small amounts, typically amounting only to $1-2 \%$ of the total sterol fraction. Phytosterols are found in plant tissues as free steroids and in a variety of conjugated forms. Through the $\mathrm{C} 3$ hydroxyl group the sterols can be found esterified with fatty or phenolic acids, or glycosylated with D-glucose or acyl-glucose (Plumb et al., 2011).

Because of their structural similarity with cholesterol, dietary phytosterols reduce intestinal absorption of cholesterol and contribute to reducing serum cholesterol levels (Plat and Mensink, 2005). In plants, these compounds are involved in membrane fluidity and permeability (Hartmann, 1998; Schaller, 2003) and in embryogenesis (Schrick et al., 2011). As plant hormone-precursors, they play a crucial role in plant growth and developmental processes such as cell division, polarity and morphogenesis (Merah et al., 2012).

Sunflower oil is the fourth oil most produced in the world and its composition has a high potential to be improved for nutritional and industrial purposes through genetically selection and breeding of seeds (Mouloungui et al., 2006; Merah et al., 2012). The total sterol content of sunflower oil has been reported to range between 3000 and $4000 \mathrm{mg} / \mathrm{kg}$, being the content of free sterols $(62.4 \%)$ higher than that of the esterified forms (37.6\%) (Verleyen et al., 2002).

At present, a new sunflower oil characterized by a high content of phytosterols, ranging between 7660 and $14980 \mathrm{mg} / \mathrm{kg}$ in the unrefined oil, can be found. These elevated levels of phytosterols are not produced in nature by sunflower plants. They have been obtained through a complex genetic process consisting of artificial induction of mutations and fixation of the identified new character (Velasco et al., 2012).

The total content and composition of phytosterols in the oil depend not only on genetic and environmental factors of sunflower, but also on technological processes of oil extraction (Van Hoed et al., 2010; Fernández-Cuesta et al., 2014). Generally, the oil extraction is based on two main steps: pressing (solid-liquid expression) and solvent extraction. Mechanical and thermal pre-treatments preceded these processes and contribute to enhance their performances (Savoire et al., 2013). After the first extraction by pressure with an expeller, the resulting solid matter has a relatively high fat content (approximately $15-18 \%$ ) and it is subjected to a solvent extraction to exhaust the oil retained (Kovari, 2004). The pressed and solvent extracted oils are generally blended before storage and refining.

The growing interest of consumers for minimally processed products has recently encouraged the production of cold pressed oils (Rass et al., 2008). Compared to oils obtained by solvent extraction, the oils obtained by mechanical procedures might present an added value that makes it reasonable to commercialize the two oils separately. In this regard, it is essential to get to know the chemical composition of the oils obtained separately by pressing and solvent extraction. The objective of this study was to evaluate possible changes in the chemical composition between sunflower oils obtained separately by mechanical pressing and subsequent solvent extraction from a new line of seeds rich in phytosterols and conventional seeds. The content and composition of phytosterols were studied in detail.

\section{Materials and methods}

\subsection{Oil extraction}

HA-89 and IASP-18 seeds, with conventional and high phytosterol content, respectively, were conditioned at $70{ }^{\circ} \mathrm{C}$ for $60 \mathrm{~min}$. The oil was extracted using a small expeller press, Täby Pressen model 40a (Skeppsta Maskin AB, Örebro, Sweden), with a capacity of $3.5 \mathrm{~kg} \mathrm{~h}^{-1}$. Whole sunflower seeds were used because it is known that husked seeds are plasticized in the screw press and the drainage canals can be blocked (Rass et al., 2008). Moisture content of samples was $10 \%$ when expelled.

The oil retained in the pellets was further extracted with $2.5 \mathrm{~L}$ hexane during $4 \mathrm{~h}$ at $60{ }^{\circ} \mathrm{C}$ in a Soxhlet extractor with a capacity for solids of $2 \mathrm{~kg}$. Then the solvent was removed under vacuum.

\subsection{Analytical methods}

The total content of oil in the seeds was determined from ground seeds using a Soxhlet extractor according to official method UNE 55-062 (AENOR, 1991). Free fatty acids were determined following method UNE 55-011 (AENOR, 1991).

Unsaponifiable fractions were extracted from $2 \mathrm{~g}$ of oil, adding $1 \mathrm{mg}$ of $\alpha$-cholestanol as internal standard, following the standard method UNE 55-004 (AENOR, 1991). The standard procedure was followed by a last extraction step using $50 \mathrm{ml}$ chloroform to increase the extraction of polar compounds.

Free sterols and steryl glycoside quantification was performed following the method proposed by Aguirre et al. (2012). Sterols were determined in the lipid unsaponifiable matter. The extract was dissolved in pyridine so as to obtain a $5 \mathrm{mg} / \mathrm{ml}$ solution. An aliquot of $200 \mu \mathrm{L}$ was derivatized with $200 \mu \mathrm{L}$ of pyridin:hexamethyldisilazane: chlorotrimethylsilane (9:3:1). After $15 \mathrm{~min}$ at $70{ }^{\circ} \mathrm{C}$, the sylanized unsaponifiable fraction was directly analysed by hightemperature gas-liquid chromatography using an Agilent 6850 Series chromatograph (Agilent, Avondale, PA, USA) equipped with an on-column injector, an HP-5 capillary column $(15 \mathrm{~m} \times$ $0.25 \mathrm{~mm}, 0.1 \mathrm{~mm}$ ) (Agilent, Avondale, PA, USA) and a flame ionization detector, set at $360{ }^{\circ} \mathrm{C}$. The analyses were run using hydrogen as carrier gas $(1 \mathrm{~mL} / \mathrm{min})$ and with the following oven temperature program: $80{ }^{\circ} \mathrm{C}$ (held for $1 \mathrm{~min}$ ), rising up to $220^{\circ} \mathrm{C}$ at $20^{\circ} \mathrm{C} / \mathrm{min}$ and then rising at $10{ }^{\circ} \mathrm{C} / \mathrm{min}$ up to $350{ }^{\circ} \mathrm{C}$ (held for $15 \mathrm{~min}$ ). A correction factor of 1.06 was applied in the quantification of sterol glycosides.

Sterol Esters were quantified following the Tuckey and Stevenson method (1979). 
Table 1. Oil content (\% w/w) extracted from a new line of sunflower seeds rich in phytosterols (IASP-18) and conventional seeds (HA-89) by pressing and subsequent solvent extraction compared to total oil determined by Soxhlet.

\begin{tabular}{ccc}
\hline & IASP-18 & HA-89 \\
\hline Pressing extraction & 2.9 & 20.0 \\
Solvent extraction $^{\text {a }}$ & 17.6 & 18.4 \\
Analytical results (Soxhlet) & 18.1 & 37.5 \\
\hline
\end{tabular}

Mean $(n=2) .{ }^{\text {a }}$ Extraction of the oil retained in the pellets after pressing extraction.

Fatty acids were determined by GC after derivatization of the oil to fatty acid methyl esters with $2 \mathrm{~N} \mathrm{KOH}$ in methanol, according to UNE 55-037 method (AENOR, 1991). An HP-7890 (Hewlett-Packard, Palo Alto, CA, USA) equipped with an SP-2380 (Supelco, Bellefonte, PA, USA) capillary column of fused silica ( $30 \mathrm{~m} \times 0.32 \mathrm{~mm}$ I.D., $0.2 \mu \mathrm{m}$ film thicknesses) and a flame ionisation detector (FID). Hydrogen was used as carrier gas with a linear rate of $28 \mathrm{~cm} \mathrm{~s}^{-1}$. The oven temperature was maintained at $170{ }^{\circ} \mathrm{C}$, and that of the injector and the detector at $220^{\circ} \mathrm{C}$. The injection split ratio was 1:50.

Tocopherols were determined by HPLC with fluorescence detection (excitation at $290 \mathrm{~nm}$ and emission at $330 \mathrm{~nm}$ ), following the IUPAC Standard Method 2.432 (IUPAC, 1991). n-Hexane:isopropanol (99:1, by vol.) as mobile phase at a flow rate of $1 \mathrm{~mL} \mathrm{~min}^{-1}$ and a LiChrosorb Si $60(250 \times 4 \mathrm{~mm})$ column packed with silica ( $5 \mu \mathrm{m}$ particle size) (Merck, Darmstadt, Germany) were used. Oil solutions of $50 \mathrm{mg} \mathrm{mL}^{-1}$ were analysed.

The oil stability index (OSI) was determined following AOCS method number Cd 12b-92 (AOCS, 2008) using a Rancimat (Metrohm Ltd., Herisau, Switzerland) at $110^{\circ} \mathrm{C}$ and an air flow of $20 \mathrm{~L} \mathrm{~h}^{-1}$.

\section{Results and discussion}

The total content of oil was much lower in the IASP-18 $(18.1 \%)$ than in the conventional $(37.5 \%)$ seeds (Tab. 1$)$. The extraction yield obtained by pressing was as low as $3 \%$ in the IASP-18 seeds and $37.5 \%$ in the HA- 89 seeds, while the yield in the solvent extraction was of the same order $(\sim 18 \mathrm{wt} \%$ on seeds extracted by pressing) for the two types of seeds. In addition, the total content of oil obtained by the sum of both extraction procedures was similar to that obtained in the standard method with Soxhlet.

The oils obtained by the two extraction procedures presented similar fatty acid composition (Tab. 2). However the oils extracted by pressing showed significantly larger content of the unsaponifiable matter, being the differences more pronounced in the IASP-18 oils. On the contrary, the oils extracted by pressing showed significantly lower acidity and the acidity of the oils extracted with solvent was lower than $1 \%$, which is typical of high quality seeds with low hydrolysis levels. The lower acidity found for the pressed oils are in agreement with studies of other authors (Fernández- Cuesta et al., 2014; Van Hoed et al., 2010).

The content of tocopherol was higher for the IASP-18 oil and slight differences were also found between the oils extracted with different extraction methods (Tab. 2). The oils extracted by pressing were approximately $10 \%$ more concentrated in tocopherol. The oxidative stability was lower for the IASP-18 oils and can be attributed in part to the larger content of linoleic acid. There were slight differences between the oxidative stability values of the oils extracted by pressing and solvent, although such differences were not consistent. While the stability of the oil extracted by pressing was higher in the IASP-18 seeds, the opposite was found in the HA-89 oils. Therefore the differences found in the oxidative stability can not be accounted by the slight differences in the content of tocopherols. Fernández-Cuesta et al. (2014) have also reported discrepancies between oil stability values of crude pressed oils and oils subsequently extracted by solvent from safflower seeds and that such varying results could be explained by small differences in minor components of antioxidant or prooxidant effects.

Table 3 lists results obtained for the total content of sterols and their composition. The total sterols were $37-38 \%$ more concentrated in the oils extracted with solvent, reaching amounts of 13700 and $6500 \mathrm{mg} / \mathrm{kg}$ in the IASP-18 and HA-89 oils, respectively. In this regard, other authors have also reported higher contents of sterols in oils extracted by solvent from different seeds compared to cold-pressed oils (Fernández-Cuesta et al., 2014; Van Hoed et al., 2010; Li et al., 2007). Unlike other similar studies on other oleaginous seeds (Fernández-Cuesta et al., 2014; Van Hoed et al., 2010; Li et al., 2007), no substantial differences were found in the present study in the composition of total sterols analysed as free sterols between the oils extracted with the two procedures.

Significant differences were however found for the different classes of sterols (Tab. 4). In the IASP18 sample, 52.3\% of sterols was found in the free form in the mechanically extracted oil, whereas $63.0 \%$ was obtained in the oil extracted by solvent. A higher relative concentration of free sterols in the oil extracted with solvent was also found in the conventional sunflower sample, being of $78 \%$ against $60 \%$ in the oil obtained by mechanical extraction. The relative concentration of complex sterols was obviously greater in the oils obtained by mechanical extraction. Thus the sterol esters constituted 44 and $39 \%$ (w/w, expressed as free sterols) of total sterols in the oils extracted by pressing and solvent, respectively, from the IASP18 sample, and 41 and $25 \%$ (w/w, expressed as free sterols) in the oils from conventional seeds, respectively. The amount of sterol glycosides was very low but significantly much higher, in a factor of 8 , in the oils extracted with solvent.

The larger total content of sterols and the higher proportion of those with larger polarity, i.e. free sterols and sterol glycosides, in the oils extracted with solvent can be attributed to a greater extractive capacity of the Soxhlet extraction compared to the pressing procedure. In the first step, i.e. pressing extraction, the solubility of minor components in the oil mainly depends on the content of oil released, which acts like a solvent. Once the oil available is saturated this can not incorporate more sterols. On the contrary, in the Soxhlet extraction, the sterols along with the neutral lipids are extracted with solvent, which is saturated in sterols in each extraction cycle and these are concentrated in the oil as a result. In addition, due to the greater solubility in the oil of those sterols with less 
Table 2. Physical and chemical characteristics of crude sunflower oils extracted by mechanical press and subsequent solvent extraction from a new line of seeds rich in phytosterols (IASP-18) and conventional seeds (HA-89).

\begin{tabular}{|c|c|c|c|c|}
\hline & \multicolumn{2}{|c|}{ IASP-18 } & \multicolumn{2}{|c|}{ HA-89 } \\
\hline & Pressing & Solvent & Pressing & Solvent \\
\hline $\begin{array}{c}\text { Acidity* } \\
(\% \text { on oleic) }\end{array}$ & 0.56 & 0.72 & 0.18 & 0.85 \\
\hline \multicolumn{5}{|l|}{ Major Fatty acids* (\%) } \\
\hline C16:0 & 8.0 & 9.6 & 6.4 & 7.1 \\
\hline C16:1 & 0.3 & 0.4 & 0.2 & 0.2 \\
\hline C18:0 & 1.9 & 1.9 & 4.2 & 4.0 \\
\hline C18:1 & 16.2 & 16.4 & 45.6 & 44.3 \\
\hline $\mathrm{C} 18: 2$ & 72.2 & 71.1 & 42.4 & 43.3 \\
\hline $\mathrm{C} 20: 0$ & 0.2 & 0.1 & 0.3 & 0.3 \\
\hline $\mathrm{C} 22: 0$ & 0.2 & 0.5 & 0.7 & 0.6 \\
\hline Others & 1.0 & 0.1 & 0.3 & 0.2 \\
\hline Unsaponifiable Matter* (\%) & 2.89 & 2.13 & 2.53 & 2.37 \\
\hline $\begin{array}{l}\text { Tocopherols Conc.* } \\
\qquad\left(\mathrm{mg} \mathrm{kg}^{-1}\right)\end{array}$ & 875 & 803 & 651 & 588 \\
\hline $\begin{array}{c}\text { Stability* } \\
\left(\text { Rancimat } 110^{\circ} \mathrm{C}, \mathrm{h}\right)\end{array}$ & 6.2 & 8.0 & 14.9 & 11.7 \\
\hline
\end{tabular}

* Mean $(n=2)$.

Table 3. Sterol content and composition in crude sunflower oils extracted by mechanical press and subsequent solvent extraction from a new line of seeds rich in phytosterols (IASP-18) and conventional seeds (HA-89).

\begin{tabular}{cccccc}
\hline & \multicolumn{2}{c}{ IASP-18 } & & \multicolumn{2}{c}{ HA-89 } \\
\cline { 2 - 3 } \cline { 5 - 6 } \cline { 5 - 6 } Pressing & Solvent & & Pressing & Solvent \\
\hline Sterols Conc. $\left(\mathrm{mg} \mathrm{kg}^{-1}\right)$ & $9956 \pm 15$ & $13703 \pm 346$ & & $4757 \pm 212$ & $6520 \pm 316$ \\
Composition (\%) & & & & & \\
Campesterol & 4.5 & 5.2 & & 4.9 & 5.0 \\
Stigmasterol & 5.1 & 5.5 & & 4.0 & 6.9 \\
$\beta$-Sitosterol & 68.9 & 69.6 & & 67.7 & 68.5 \\
$\Delta^{5}$-Avenasterol & 2.1 & 0.7 & & 0.7 & 2.4 \\
$\Delta^{7}$-Stigmastenol & 14.6 & 14.8 & & 16.9 & 13.2 \\
$\Delta^{7}$-Avenasterol & 2.3 & 2.8 & & 3.0 & 1.9 \\
Others & 2.2 & 1.8 & & 2.8 & 2.0 \\
\hline
\end{tabular}

Table 4. Sterol composition by classes in crude sunflower oils extracted by mechanical press and subsequent solvent extraction from a new line of seeds rich in phytosterols (IASP-18) and conventional seeds (HA-89).

\begin{tabular}{cccccc}
\hline & \multicolumn{2}{c}{ IASP-18 } & & \multicolumn{2}{c}{ HA-89 } \\
\cline { 2 - 3 } \cline { 5 - 6 } \cline { 5 - 6 } & Pressing & Solvent & & Pressing & Solvent \\
\hline Free sterols* $\left(\mathrm{mg} \mathrm{kg}^{-} 1\right)$ & $5512 \pm 232$ & $8636 \pm 391$ & & $2856 \pm 73$ & $5086 \pm 373$ \\
Sterol esters* $\left(\mathrm{mg} \mathrm{kg}^{-} 1\right)$ & & & & & \\
$\mathrm{a}$ & $4414 \pm 235$ & $5402 \pm 470$ & & $1971 \pm 30$ & $1639 \pm 105$ \\
$\mathrm{~b}$ & $7327 \pm 290$ & $8967 \pm 780$ & & $3272 \pm 50$ & $2721 \pm 174$ \\
Sterol glycosides* $\left(\mathrm{mg} \mathrm{kg}^{-} 1\right)$ & $32 \pm 6$ & $268 \pm 55$ & & $16 \pm 1$ & $138 \pm 28$ \\
\hline
\end{tabular}

* Mean $(n=3) \pm$ SD. ${ }^{a}$ Sterol esters expressed as free sterols. ${ }^{\mathrm{b}}$ Sterol esters calculated from the equation $b=a \times 1.66$. 
polarity, i.e. sterol esters, compared to free sterols, the seeds that result after the pressing extraction have increased relative concentrations of free sterols and sterol glycosides. The same reasoning might explain the higher acidity values found in the oils extracted with solvent.

\section{Conclusions}

The results of this study have shown that the oils obtained by pressing from IASP-18 and HA-89 seeds do not differ from those by solvent extraction in terms of fatty acid composition, although the pressed oils showed significantly larger content of unsaponifiable material. The main differences were observed in the total content of sterols, being substantially much higher in the solvent extracted oils. Thus, total sterols were $37-38 \%$ more concentrated in the oils extracted with solvent, reaching amounts of 13700 and $6500 \mathrm{mg} / \mathrm{kg}$ in the IASP18 and HA-89 oils, respectively. No substantial differences were found in the composition of total sterols analysed as free sterols between the oils extracted with the two procedures, but significant differences were found for the different classes of sterols. The contents of free sterols and sterol glycosides were much higher in the oils extracted with solvent and the oils extracted by pressing were characterized by higher relative concentrations of sterol esters.

Acknowledgements. The authors thank Irene Pérez de la Rosa, for technical assistance. This work was supported by Research Project AGR 20073011 from Junta de Andalucía and EU FEDER funds.

\section{References}

AENOR. 1991. Catálogo de Normas UNE. Asociación Española de Normalización, Madrid.

Aguirre MR, Ruiz-Méndez MV, Velasco L, Dobarganes MC. 2012. Free sterols and steryl glycosides in sunflower seeds with high phytosterol contents. Eur. J. Lipid Sci. Tech. 114: 1212-1216.

AOCS. 2008. Official Methods and Recommended Practices, 6th ed. American Oil Chemists' Society. AOCS Press, Champaign.

Fernández-Cuesta A, Velasco L, Ruiz-Méndez MV. 2014. Novel safflower oil with high $\gamma$-tocopherol content has a high oxidative stability. Eur. J. Lipid Sci. Tech. 116: 832-836.

Hartmann MA. 1998. Plant sterols and the membrane environment. Trends Plant Sci. 3: 170-175.

IUPAC. 1991. Method 2.432. Determination of tocopherols and tocotrienols in vegetable oils and fats high performance liquid chromatography. In: Standard methods the analysis of oils, fats and derivatives, 7th edition. In: Oxford: Pergamon Press.
Kovári K. 2004. Recent developments, new trends in seed crushing and oil refining. $O C L$ 11: 381-387.

Li TSC, Beveridge THJ, Drover JCG. 2007. Phytosterol content of sea buckthorn (Hippophae rhamnoides L.) seed oil: Extraction and identification. Food Chem. 101: 1633-1639.

Merah O, Langlade N, Alignan M, Roche J, Pouilly N, Lippi Y, Vear F, Cerny M, Bouniols A, Mouloungui A, Vincourt P. 2012. Genetic analysis of phytosterol content in sunflower seeds. Theor. Appl. Genet. 125: 1589-1601.

Mouloungui Z, Roche J, Bouniols A. 2006. Limitations extractives des ingredients fonctionnels natifs: lipides bioactifs par modifications chimiques. $O C L$ 13: 16-22

Piironen V, Lindsay DG, Miettinen TA, Toivo J, Lampi AM. 2000. Plant sterols: biosynthesis, biological function and their importance to human nutrition. J. Sci. Food Agr. 80: 939-966.

Plat J, Mensink RP. 2005. Plant stanol and sterol esters in the control of blood cholesterol levels: mechanism and safety aspects. Am. J. Cardiol. 96: 15-22.

Plumb JA, Rhodes MJ, Lampi AM, Buchgraber M, Kroon PA. 2011. Phytosterols in plant foods: Exploring contents, data distribution and aggregated values using an online bioactives database. J. Food Comput. Anal. 24: 1024-1031.

Rass M, Schein C, Matthäus B. 2008. Virgin sunflower oil. Eur. J. Lipid Sci. Technol. 110: 618-624.

Roche J, Alignan M, Bouniols A, Cerny M, Mouloungui Z, Merah O. 2010. Sterol concentration and distribution in sunflower seeds (Helianthus annuus L.) during seed development. Food Chem. 119: 1451-1456.

Savoire R, Lanoisellé JL, Vorobiev E. 2013. Mechanical continuous oil expression from oilseeds: a review. Food Bioprocess. Technol. 6: $1-16$

Schaller H. 2003. The role of sterols in plant growth and development. Progr. Lipid Res. 42: 163-175.

Schrick K, Cordova C, Li G, Murray L, Fujioka, S. 2011. A dynamic role for sterols in embryogenesis of Pisum sativum. Phytochemistry 72: 465-475.

Tuckey RC, Stevenson PM. 1979. Methanolysis of cholesteryl esters: conditions for quantitative preparation of methyl esters. Anal. Biochem. 94: 402-408.

Van Hoed V, Ben All C, Slah M, Verhé R. 2010. Quality differences between prepressed and solvent extracted rapeseed oil. Eur. J. Lipid Sci. Tech. 112: 1241-1247.

Velasco L, Fernández J M, Pérez-Vich B, Fernández-Cuesta A. 2012. Sunflower oil having a high phytosterol content. (27.12.2012) WO 2012/175772A2.

Verleyen T, Forcades M, Verhé R, Dewettinck K, Huyghebaert A, De Greyt W. 2002. Analysis of free and esterified sterols in vegetable oils. J. Am. Oil Chem. Soc. 79: 117-122.

Vlahakis C, Hazebroek J. 2000. Phytosterol accumulation in canola, sunflower, and soybean oils: effects of genetics, planting location, and temperature. J. Am. Oil Chem. Soc. 77: 49-53.

Cite this article as: Marta R. Aguirre, Joaquín Velasco, M. Victoria Ruiz-Méndez. Characterization of sunflower oils obtained separately by pressing and subsequent solvent extraction from a new line of seeds rich in phytosterols and conventional seeds. OCL 2014, 21(6) D605. 